\title{
Socio-Anthropological Factors as Sources of Desecration of Grébouo 1 Sacred Grove, Southwestern Cote d'Ivoire
}

\author{
Mouroufie Kouman Kouassi Vincent \\ Institut d'Ethno-Sociologie, Université Félix Houphouët Boigny \\ d'Abidjan-Cocody, Abidjan, Côte d'Ivoire \\ Centre Suisse de Recherches Scientifiques en Côte d'Ivoire, Abidjan \\ Koffi Maxime Valdier \\ Ogni Kanga Benoit \\ Institut d'Ethno-Sociologie, Université Félix Houphouët Boigny \\ d'Abidjan-Cocody, Abidjan, Côte d'Ivoire

\section{Bitty Anderson} \\ Centre Suisse de Recherches Scientifiques en Côte d'Ivoire, Abidjan \\ Laboratoire de Zoologie et Biologie Animale, \\ Université Félix Houphouët Boigny d'Abidjan-Cocody, Côte d'Ivoire \\ Gonedele Bi Seri \\ Centre Suisse de Recherches Scientifiques en Côte d'Ivoire, Abidjan \\ Departement de Génétique, Université Félix Houphouët Boigny \\ d'Abidjan-Cocody, Côte d'Ivoire
}

URL:http://dx.doi.org/10.19044/esj.2019.v15n5p178

\begin{abstract}
This paper focuses on investigating the threats affecting Grébouo 1 forest grove (GFG) and their socio-anthropological drivers. Sociological surveys consist of semi-structured interviews and individual discussions among communities' elders and households in four nearest villages surrounding GFG. The taboos implied a ban on damaging or disrespecting the area. Disrespecting the area included burning, hunting, cutting, and polluting the area through defecating, urinating, or sexual activities. Natives are the community that mostly (88\%) collect plant resources inside GFG compared to Ivorian and West African migrants (5 and 11\% respectively). For all the respondents, GFG is a place of supply (92\% of the respondents) and secondly is a holy place (5\% of the respondents). The rarefaction of forest resources in GFG region poses threats to the grove since the traditional beliefs ruling its management is no longer respected. The preservation of this grove
\end{abstract}


necessitates the reconciliation between traditional beliefs, economic needs, and nature conservation.

Keywords: Grébouo 1, Sacred groves, Desecration, Traditional values, Social representation

\section{Introduction}

Sacred groves, also known as church forests, fetish forests and sacred forests, are areas of vegetation preserved through local taboos and sanctions that express ecological and spiritual values (Agyepong, Nabila, Gyasi \& Kufogbe, 1999). Available literature reveals that sacred groves are a global phenomenon (Gupta, 1980) with high similarity in the cultural and ecological dimensions of their management in Africa (Campbell, 2004), Asia (Malhotra, Gokhale, Chatterjee \& Srivastava, 2001), Europe (Lucas, 1968), Latin America (Acha, 2003), and Australia (Elias, 2003).

Consequently, this traditional conservation practices in the form of nature worship have played an important role in the protection and conservation of biodiversity (Bhagwat \& Rutte, 2006). Recent work shows that many rare and endemic species are found only in sacred groves (Dudley, Higgins-Zogib \& Mansourian, 2009).

In turn, these forests provide essential ecosystem services that include both the material provisions (timber and non-timber forest products), nonmaterial (spiritual value, cultural value), and support services (nutrient cycling, water storage, carbon storage, pollination) (Bhagwat, 2009; Powledge, 2006).

Due to their importance, both the UNESCO-MAB biosphere reserve concept (UNESCO, 1996) and the World Heritage Convention (UNESCO, 1972) clearly recognize the importance of sacred sites/groves and place them into the context of sustainable development.

In Côte d'Ivoire, more than 6702 sacred forests covering an extent of 37000 hectares were listed (Gomé, 2003). With the continuing decline of the forest cover of Côte d'Ivoire, the importance of forest groves are to be reinforced. Indeed, with an estimated sixteen million hectares of high canopy forest at the outset of the 20th century, the forest cover of Côte d'Ivoire has declined to four million ha and is declining due to an annual deforestation rate of approximately 1\% (Achard et al., 2002; Brou et al., 1999; Léonard \& Ibo, 1994; Tutu \& Akol, 2009). Côte d'Ivoire's remaining forest is highly fragmented, consisting largely of nominally protected national parks and forest reserves, i.e. "protected areas" (PAs), and is continuously on a decline due to encroachment for agriculture purpose. The failure of the traditional conservation systems of PA highlights the importance of sacred groves as an alternative. 
Despite their protection by the religious prohibitions, sacred forests are facing strong anthropogenic pressures because of the decreasing of local resources and the loss of traditional values, posing threat to several threatened taxa (Garcia, Pascal \& Kushalappa, 2006; Gonedelé Bi, Bitty, Ouatara, \& McGraw, 2014; Kokou, 1998).

Since the forest grove of Grébouo 1 is the only forest fragment that subsisted in a region predominated by cocoa and oil palm-based agro-forestry, it provides an ideal situation to test the adaptation of this forest to cultural and anthropogenic pressures.

In 2013, previous survey in GFG indicated poaching pressure and illegal logging as an important threat to the forest survival (Gonedelé Bi, Bitty \& McGraw, 2013). Local community protection of the sacred groves was evidently warning. It was hypothesized that the decline in effective protection of the sacred groves was due to the fact that their cultural roles and values in local people's lives had diminished and could pose severe threat to the survival of GFG in a very near future.

Therefore, the objectives of this study were to identify: (i) the traditional cultural values for which the native population conserved the sacred groves; (ii) the effectiveness of sacred groves relative to traditional beliefs; and (iii) Societal attributes responsible for the persistence and non respect of the taboos related to GFG.

\section{Material and Methods \\ Study Site}

Grébouo 1 (UTM coordinates: N 0793849; W 0626724) is a remote village in the Department of Soubré, southwestern Côte d'Ivoire, approximately $45 \mathrm{~km}$ from the town of Soubré and $100 \mathrm{~km}$ from Gagnoa (Figure 1).

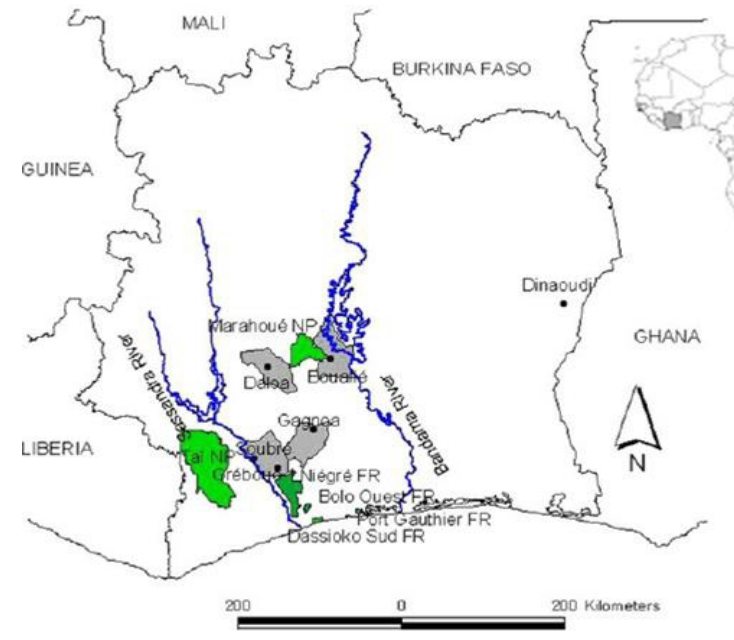

Figure 1. Map of Côte d'Ivoire showing the location of Grébouo 1 
The forest which is approximately 16 ha in size is immediately adjacent to the village. GFG owes its existence to the beliefs, culture, and history of the local people consisting of Bété ethnic group. Communities and village elders act as guardians of the sacred site and cutting of trees or destruction of vegetation is prohibited. Traditional beliefs have been an important component of the preservation of the forest grove.

The study included all the villages located at less than $5 \mathrm{~km}$ of GSG. They are: Grébouo 1, Dioulabougou, Monèkro, and Srakakoffikro. These villages belong to the administrative unit of Okrouyo located at approximately $35 \mathrm{~km}$ of Soubré, which is the administrative center of the Department. A historical bond exists between the villages of Dioulabougou, Monèkro, Srakakoffikro, and Grébouo 1. In fact, the populations living in the first three villages mentioned were installed by the natives of Grébouol who sold or lend them their land for agriculture purpose. The villages of Dioulabougou, Monèkro, and Srakakoffikro are characterized by the fact that their sociolinguistic component groups are only immigrants and foreigners. Among these populations, according to a demographic order of importance, we listed Baoulés, Malians, and Burkinabes. The economy of the area is dominated by agriculture, leading to the complete replacement of the forest ecosystems by cocoa, rubber, and oil palm plantations. The immigrants and foreign populations hold the largest plantations of cocoa, oil palm tree and rubber, and they play an important economic role in the zone.

\section{Data Collection}

The study is part of a mixed approach (qualitative and quantitative) with a predominance of the quantitative approach. Data were collected over the period from August to October 2012 in the four closest villages $(<5 \mathrm{~km})$ surrounding GFG (Grebouo 1, Dioulabougou, Srakakoffikro, Monèkro).

The data was collected using an observation grid, a semi-structured interview guide, and a questionnaire. The interview guide was used to conduct individual and group interviews with key informants. These interviews made it possible to grasp, through the discourses produced, the persistence and loss of cultural values as well as their respective possible explanations, the types of desacralization in and around the GFG1, and the perceptions of it by the local residents. Social observation has made it possible to observe and highlight desacralization practices in and around FSG1. These individual and group interviews with these different key actors, as well as the direct observation, completed and enriched the quantitative data collected through the questionnaires.

For the quantitative data, a total of 117 households were interviewed. These include 24 households in Grébouo 1, 34 in Dioulabougou, 33 in Srakakoffikro, and 25 in Monèkro. The linguistic composition of the target 
population is as follows: native (Bété), Ivorian immigrants (Baoulés, Agni, Malinké, Wobè, Tagbanan, Sénoufo), and West African immigrants (Burkinabe, Malian, Ghanaian, Nigerian, Beninese). The interviews were conducted in the language best understood by the respondents, namely French, Bété, Baoulé or Dioula. The study concerned the heads of households of the four villages. This category of actors was selected to collect reliable information about the desecration of the sacred forest of Grebouo 1.

In terms of qualitative data, the number of participants is 83 and is made up of 20 community leaders (community leaders, leaders of youth and women's associations, religious guides) and 63 community members (youth and adults from the community of two sexes), i.e. 28 young people and 35 adults. 20 individual interviews were conducted with community leaders and 9 focus groups with community members for all four surveyed villages. Participants were selected based on permanent residence in the study area, status (community leader, leaders of youth and women's associations, religious guide, housewife, planter and trader), and their willingness to participate as well as their potential to bring relevant knowledge. This included older men and women who could become familiar with groves and associated practices, as well as a mix of traditional Christians and worshipers.

The collected data was processed using SPSS 17.0 software and content analysis: Statistical analyzes were performed using SPSS 17.0 (Windows software package, SPSS Inc., Chicago, USA, SPSS, 2009). We used Spearman's rank correlation coefficient (two tails) to test the correlation trends between geographic distance and the frequency of taboo transgressions. The Ki-2 test was also used to verify the difference between: (1) the level of education of indigenous and migrant people; and (2) the perception of communities about the role of GFGs. The qualitative analysis was essentially a content analysis of the interviews. The persistence and loss of cultural values and their respective possible explanations were summarized for each respondent and then compiled for the entire group.

\section{Results}

\section{Sample Characteristics}

Among the 117 households interviewed, the large majority of respondents was male $(75.22 \%$ male and $24.78 \%$ female) with lower educational backgrounds. Most of the households (86.32\%) were farmers.

The majority of respondents were Christian (43.59\%) or Muslim (34.19\%). These two religions are by far followed by Animist (10.26\%). At the community level, natives or Ivorian migrants are in majority Christian (75\% and $80 \%$ respectively), whereas West African migrants are in majority Muslim (89.47\%). 
Most of the respondents $(83 \%)$ have no education level or are of poor educational level. Only 1 respondent $(1 \%)$ has been to the university while 19 $(16 \%)$ have been to secondary school. There were no significant difference between the level of education of natives and Ivorian migrants $(\chi 2=.858$, df $=3, p=.836$ ). Ivorian, whether natives or Ivorian migrants, have significantly higher levels of education than West African migrants (Natives vs. West African migrants: $\chi 2=41.768, \mathrm{df}=4, p<.0001$; Ivorian migrants vs. African migrants: $\chi 2=63.90, \mathrm{df}=3, p<.0001)$.

\section{Taboos Related to the Forest Grove}

The respect and protection of the Grébouo 1 forest grove originates from the reverence of the Iroko tree (Chlorophora excelsa) for its social function as a protector and giver of fecundity and also for the fear to animals living in the forest that are considered as ancestral spirits. The taboos implied a ban on damaging or disrespecting the area (Table 1).

Table 1. Taboos related to the Grébouo 1 forest grove

\begin{tabular}{|l|}
\hline Hunting inside the sacred grove \\
\hline Collection of plant resources including: \\
$1 . \quad$ trees \\
$2 . \quad$ medicinal plants \\
$3 . \quad$ rattans \\
$4 . \quad$ fire woods \\
$5 . \quad$ leaves \\
$6 . \quad$ liana \\
$7 . \quad$ others ..... \\
\hline Non access to the forest grove to: \\
9. pregnant women \\
10. womstruating women having a baby \\
11. foreigners \\
\hline Defecation inside the forest grove \\
\hline Urination inside the forest grove \\
\hline Sexual activities inside the forest grove \\
\hline Setting fire inside the forest grove \\
\hline
\end{tabular}

Disrespect included burning, cutting, and polluting the area through defecating, urinating, or sexual activities. The taboo also includes restriction of foreigners from gaining entrance into the forest, unless they are allowed by traditional authorities.

Harvest of goods in the forest grove is highly restricted. It is also a taboo for menstruating or pregnant women to enter into the grove and also women with baby.

If either case applies, the sacrifice will proceed, but she will wait on the fringe of the grove while the others sacrifice on her behalf. Enforcement of the taboos is the responsibility of the traditional authorities that rule the 
grove. If forest damage is found, a clan meeting is called to establish guilt and sanctions, following institutionalized procedures.

Basically, there are two sets of sanctions for violating the prohibitions established by the taboo: i) supernatural sanctions where ancestral or other spirits bring misfortune, disease, or death on the culprit and/or the clan or the community, and ii) physical sanctions - a penalty of zebu or sheep, the number decided by traditional authorities.

Furthermore, the penalty is paid to the traditional authorities, who then sacrifice the animals to appease the spirits and protect the culprit against punishment from the spirits.

\section{Desecretion of Grébouo 1 Forest Grove}

When asking respondents whether they poach inside the forest, Ivorian migrants were the community with the higher hunting activity $(25 \%)$ inside the grove, whereas natives and West African migrants' respondents have a low proportion hunt inside the forest (3\% and 8\% respectively) (Figure 2).

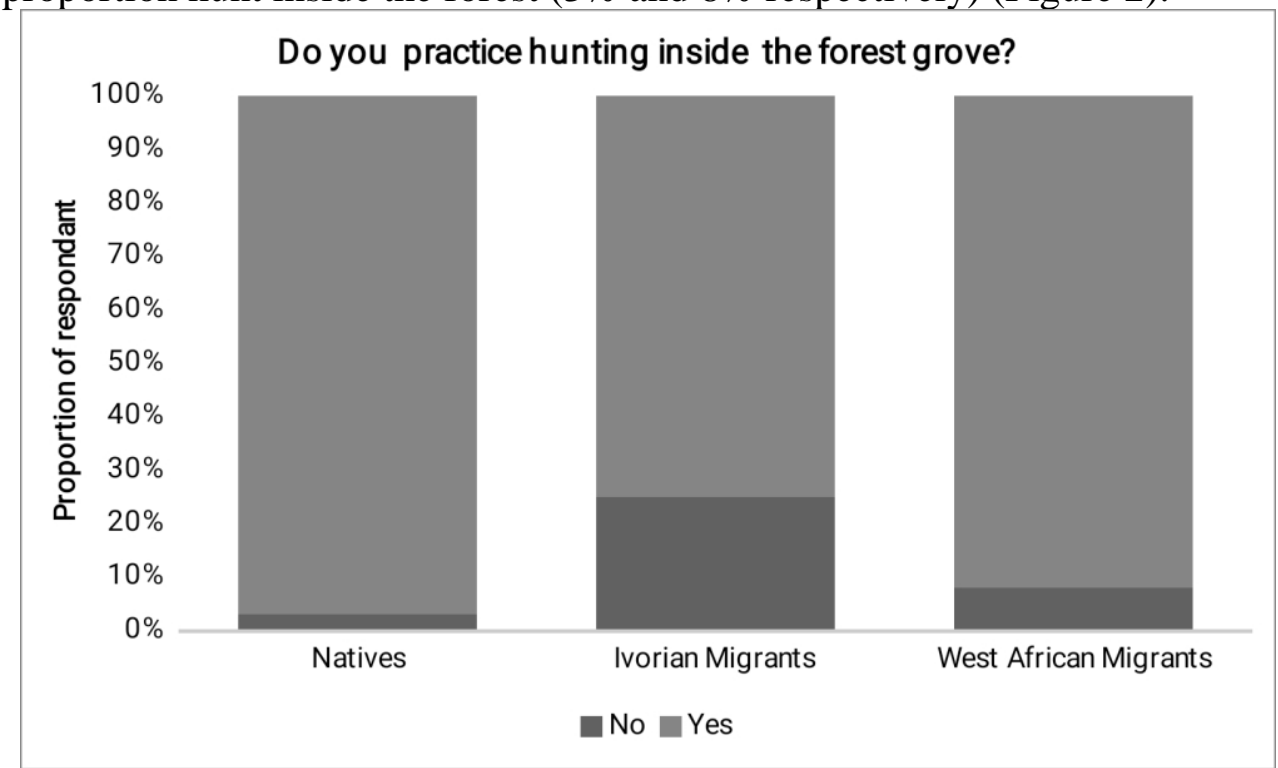

Figure 2. Proportion of respondants who reported that they hunt inside the Grébouo 1 forest (black bars) ordered by the proportion of respondants who reported that they don't hunt inside the grove (grey bars).

Natives are in their large proportion (88\%) in the community, and they mostly collect plants from the forest grove compared to Ivorian and West African migrants (5 and $11 \%$ respectively) (Figure 3). Among the plants collected, trees, bamboos and lianas come first with respectively $25 \%, 20 \%$ and $18 \%$. They are followed by leaves and medicinal plants (15 and $11 \%$ respectively). 


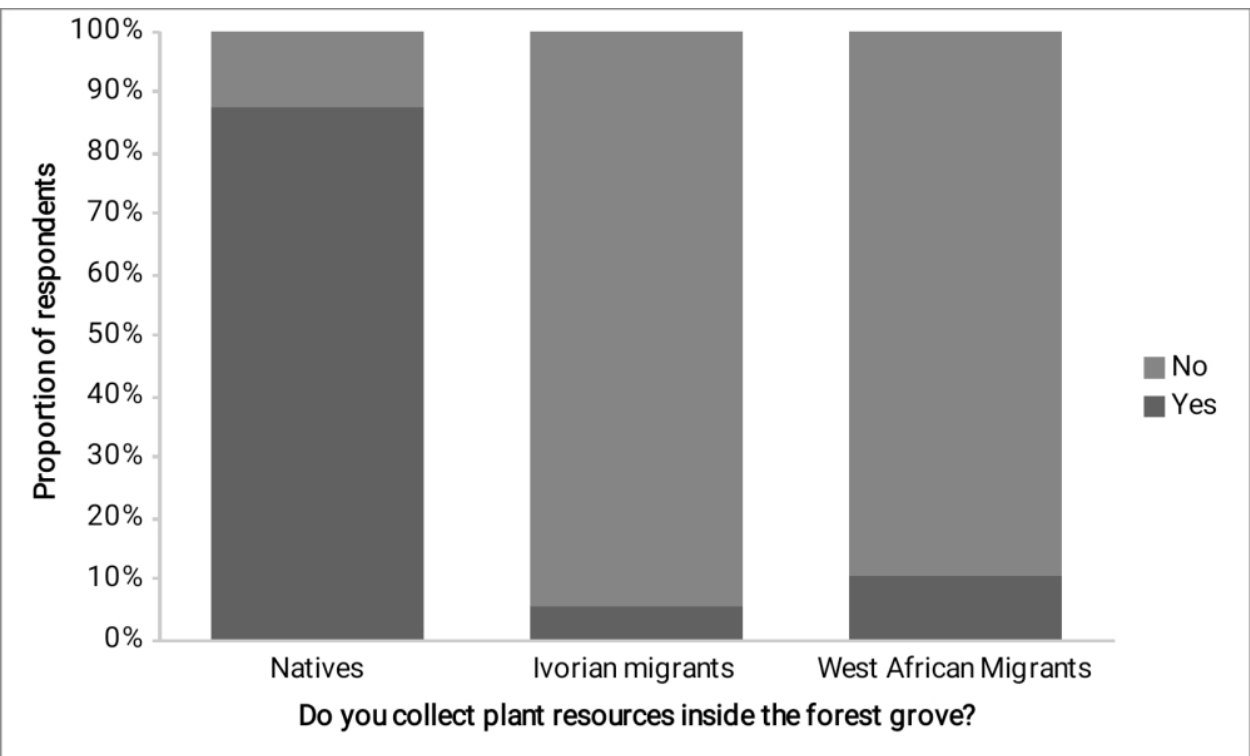

Figure 3. Proportion of respondants who reported that they collect plant resources inside the Grébouo 1 forest (black bars) ordered by the proportion of respondants who reported that they don't collect plant resources inside the grove (grey bars).

When asking respondents whether they defecate inside the grove, more than half of the natives (54\%) said yes. A very low proportion of Ivorian migrants and West African migrants (4\% and 3\%) defecate inside the grove (Figure 4).

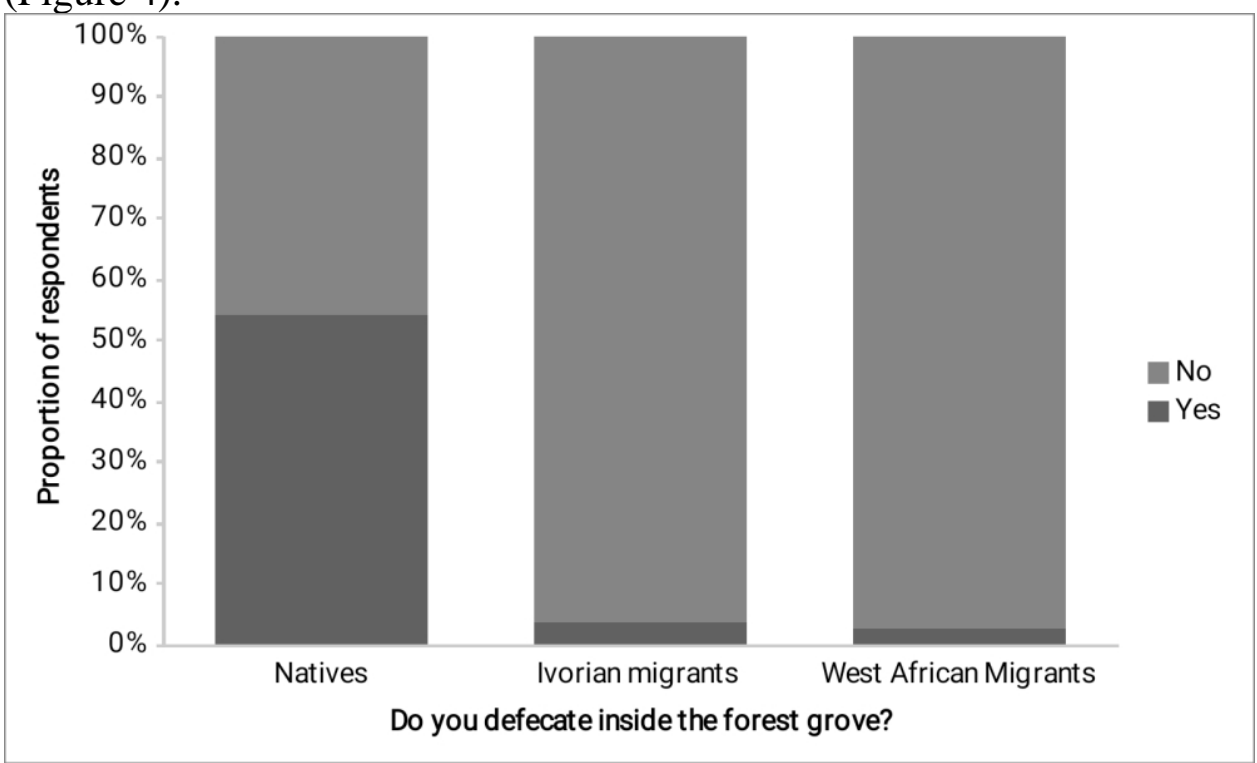

Figure 4. Proportion of respondants who reported that they defecate inside the Grébouo 1 forest (black bars) ordered by the proportion of respondants who reported that they don't defecate inside the grove (grey bars). 
A relation between the proximity of the location of the respondents and their activity inside the forest grove was established. There were no significant correlation between the distance separating the location of the respondents and poaching activity inside the grove $(\mathrm{r}=1, p=.083)$. No significant correlation was also found between the distance separating the location of the respondents and the activity of collecting plants inside the grove $(\mathrm{r}=.949, p=.167)$ or between the geographic distance and defecating inside the grove $(\mathrm{r}=-.8, p=$ .08).

\section{Perception of the Respondents on the Forest Grove}

The first perception that all the respondents (natives, Ivorian migrants and West African migrants) have to the GFG is a place of supply (92\% of the respondents) and, secondly, a holy place (5\% of the respondents) (Figure 5), both of which were significantly different $(\chi 2=8.768, \mathrm{df}=2, \mathrm{p}=.0125)$.

There were no significant difference between the perception of natives and that of Ivorian migrants on the GFG $\left(\chi^{2}=2.687\right.$, df $\left.=2, p=.261\right)$. No significant differences were also observed between the perception of natives and West African migrants $(\chi 2=3.556, \mathrm{df}=2, p=.169)$ and between Ivorian migrants and West African migrants $(\chi 2=12.174$, df $=2, p=.169)$.
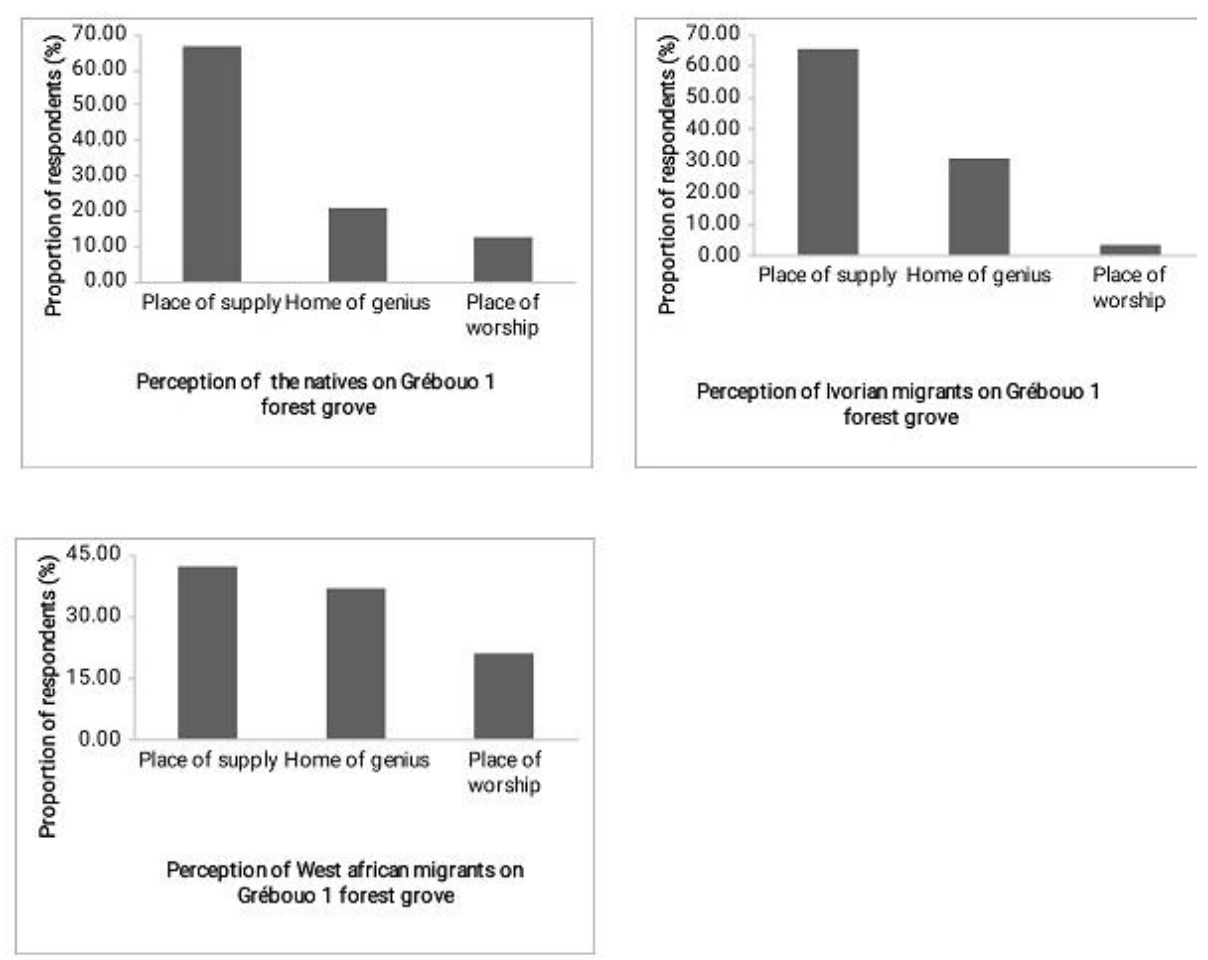

Figure 5. Perception of respondents on the role of Grébouo 1 forest grove 


\section{Discussion}

\section{Sample Characteristics}

The large majority of the head of households interviewed were male (75.22\% male and $24.78 \%$ female) with lower educational backgrounds $(83 \%)$ and with farming as their major activity (86.32\%). Christian (43.59\%) and Muslim (34.19\%) are the religions that predominate.

The sex bias structure of the sampled population could be explained by the social organization of the households interviewed which are dominated by male who have the right to lend the land. The basic social unit of the native Bété ethnic group and other migrants is the patrilineage. Thus, this explains the reason for the predominance of men in the sample. The proportion of women in our sample is composed of widows with children in care.

\section{Taboos Related to the Forest Grove}

The rationale supporting the protection of GFG is spiritual reasons rather than ecologic or economic. These beliefs coupled with the system of heavy sanctioning for transgression of the taboos have been strong enough in the past to make people obey the regulations. They believe that Iroko tree and certain wildlife species are Gods or representatives of God's protecting these plants and animals' and their habitats from any kind of threats (hunting, encroachment) and that it offers spiritual protection for the entire community. Like other traditional conservation approaches, GFG is protected, conserved, and maintained through a combination of taboos, prohibitions, beliefs, and restrictions (Akowuah et al., 1975; Anane, 1997; Dorm Adzorbu et al., 1991; Fargey, 1991; Ntiamoa-Baidu et al., 1992; Chandrakanth et al., 2004).

Traditionally, such species are strictly protected. In some cases, even touching the species is forbidden. Similar example is the Buabeng-Fiema Monkey Sanctuary in Ghana where the grove protects black and white African Colobus (Colobus polykomos) and Lowe's Mona monkeys (Cercopithecus campbelli) which are sacred to the local people (Akowuah et al., 1975; Fargey, 1991; Ntiamoa-Baidu et al., 1992) and are then strictly protected.

With regards to GFG, the entry into a sacred grove or sanctuary is strictly limited, but in other areas, they may be exploited or their use is restricted to certain forest resources (Falconer, 1992).

Although not explicitly directed towards conservation of biodiversity or ecosystem services, the taboo forests still provide considerable ecological benefits. In the context of natural resources management, they enhance biodiversity conservation and minimize the continuous use of natural resources (Abayie Boateng, 1998; Ntiamoa-Baidu, 1995). 


\section{Desecretion of Grébouo 1 Forest Grove}

Religious and cultural importance of the species is a factor that promotes the protection of GFG. However, the religious beliefs and taboos that were central on the protection of GFG are being eroded over the years due to various reasons, and thus the present status of the grove is rather precarious.

The importance of the sociologically recognized plants and animals, which have linkage with the deities of the groves or other religious practices in maintaining the ecological balance, was addressed by previous studies (Baker et al., 2009; Rodgers, 1994; Singh et al., 1998; Saj et al., 2006).

Beliefs and taboos are the constructive tools for conserving GFG, and erosion of beliefs and taboos has led to the deterioration of this grove as reported elsewhere (Chandrakanth et al., 2004; Khan et al., 2008; Ormsby \& Bhagwat, 2010; Vartak \& Gadgil, 1981; Tiwari et al., 1998; Tiwari et al., 1999; Wild \& McLeod, 2008).

The threats to effective conservation of GFG identified in this study are similar to the threats facing conservation of sacred groves elsewhere in the world (Chandrakanth et al., 2004; Khan, Khumbongmayum \& Tripathi, 2008; Schaaf, 2003; Schaaf \& Rossler, 2010; Wild \& McLeod, 2008).

However, there are several key threats that have led to the reduction in size or lack of protection of GFG. Various anthropogenic pressures due to developmental activities, exploitation of resources, and increase in human population have increased the threats to GFG. Indeed, this grove is the only forest patches in the region and it represents a kind of island of agro-industrial plantation composed of cocoa, rubber, and palm oil plantation. The rarefaction of forest resources in the area increases the threats to GFG. Indeed, local buildings are made of lianas and trees. Woods are also used for cooking by women. The only nearest place where such items are affordable is the GFG.

Our data also indicates that the natives who were questioned defecate in their large majority inside GFG. Indeed, the village of Grébouo 1 and its grove are girdled by vast plantations of oil palm trees and cocoa. With the lack of toilets in the village, the proximity of GFG seems to be an ideal and safe place from any glance. Parallel to our work, Tsialiva and Rasolomanana (2012) mentioned current practices of human defecation in the sacred site of the Mount Passot (forest) in Madagascar.

All these reasons may explain why natives that are supposed to protect the grove are those who disrespect it. This is allegated by a West Africa migrant: "It used to be sacred and one could not do that inside. But today, the Iroko where the genius used to sleep, they (Natives) have it cut down. They even defecate inside. We too defecate inside when we walk by."

In addition, the increase of human population, coupled with the erosion of traditional beliefs due to strong immigration in the area, accelerated the decline of forest resources. Immigrants often do not share the same cultural 
and spiritual values that local people have concerning the sacred grove. In some cases, this has led to further desecration of sacred groves leading to poaching inside the forest grove by immigrants. Previous studies in Côte d'Ivoire (Tahoux-Touao, 2004) and in other West African regions (Kokou, Adjossou, \& Hamberger, 2005) have reported hunting inside forest groves.

Traditional ways of resource management are becoming nonfunctional due to direct conflict between the ever increasing human population and the limited natural resources (Sinha \& Maikhuri, 1998; Kokou et al., 1999; Khurana, 1998). Unfortunately, it has been concluded in several studies (Dorm Adorbu et al., 1991; Fargey, 1991; Gyasi, 1996; Hagan, 1998; Ntiamoa-Baidu, 1995; Schaaf, 2003; Khumbongmayum et al., 2004) that the erosion of traditional beliefs threatened sacred groves and sanctuaries.

The breakdown of beliefs that protect these areas has been attributed to religion and the immigration of people who may have no respect for local traditions, and as a result of a lack of modern legislation to reinforce traditional rules (Fargey, 1991; Falconer, 1992; Ntiamoa-Baidu, 1995).

Myths and beliefs associated with the sacred groves which used to be followed strictly in earlier days have been eroded during the last few decades and the groves no longer enjoy the same status and privilege as they used to in the past (Khumbongmayum \& Tripathi, 2004).

\section{Perception of the Respondents on the Forest Grove}

GFG is perceived by the surrounding population as a supply place of natural resources. They depend on the grove to meet their vital domestic necessities, such as fuel wood, trees, bamboos, vegetables, medicinal plants, etc.

Our data indicate that economic forces are influencing the traditional communities to discard the community-oriented protection to these groves as already reported by previous studies (Saxena et al., 1998; Singh et al., 1998).

The social representations of the sacred forest by the immigrants and foreigners are related to those of the natives. Indeed, the non-compliance with the rules of management of GFG by the natives modified the attitudes and behavior of the migrants with regard to this forest. This is allegated by Boukary, a West African immigrant of Dioulabougou, who stated: "They (the natives) say that this forest is sacred, however, they do not respect it themselves. We see them; they cut wood, bamboos, lianas inside the grove, how can we respect their habits? It is because of that that we cut wood, leaves inside the grove".

It makes clear that the action of the surrounding populations on the resources of GFG is the consequence of the representations they have of it.

However, the perceptions that natives have of Grébouo 1 on their grove indicates that there is a need to reconcile myths and beliefs to economic needs 
and nature conservation. Until the surrounding population of GFG will depend on the biological resources of the grove, they will continue to violate the belief related to the grove, hence posing threats to the forest grove. Unless viable option is provided to these people for sustaining their economic condition, any step for the conservation of the sacred groves will not be successful.

\section{Conclusion}

GFG is the only remaining forest patches in the Grébouo 1 region in the otherwise intensively used landscape on which, the natives Bété and other migrant population depend for their primary needs. This pose threats to the grove since the traditional beliefs ruling the management of this holy place is no longer respected. The preservation of this grove necessitates the reconciliation between traditional beliefs - economic needs - and nature conservation. In order to counter the current threats posed to GFG due to religious and cultural changes as well as by natural resource pressures, a renewal of community traditions is needed. Local residents must continue to be involved in forest management. This may come through revival of past ceremonies related to a grove, or through awareness campaigns and education programmes highlighting the ecological and spiritual benefits of the forests. Ivorian authorities and international conservation policy should support traditional institutions of sacred forest management. Further studies need to be initiated in GFG and other groves in Côte d'Ivoire to determine the biological diversity in these forest patches and highlight their ecological and conservative values.

\section{Acknowledgements}

This research was funded by Mohamed Bin Zayed Species Conservation Fund award grant number 10251554, La Vallée Des Singes, and Primate Conservation Incorporated. We thank the traditional village authorities of Grébouo 1 for permission to carry out surveys in their sacred grove. We are also grateful to John F. Oates and McGraw S. for their help in the design. The study was supported in part by Centre Suisse de Recherches Scientifiques en Côte d'Ivoire (CSRS).

\section{References:}

1. Acha, M. O. (2003, February). Safeguarding Huichol and Seri Natural and Cultural Heritage in Mexico. Paper presented at the International Workshop on The Importance of Sacred Natural Sites for Biodiversity Conservation in Kunming and Xishuangbanna Biosphere Reserve, People's Republic of China, February 17 to 20, 2003. 
2. Achard, F., Eva, H. D., Stibig, H. J., Mayaux, P., Gallego, J., Richards, T., \& Malingreau, J. P. (2002). Determination of deforestation rates of the world's humid tropical forests. Science, 297(5583), 999-1002.

3. Agyepong, G.T., Nabila, J.S., Gyasi, E.A. \& Kufogbe, S.K. (1999). Population, land use and the environment in a West African Savanna ecosystem: an approach to sustainable land-use on community lands in northern Ghana, in Baudot, B.S. and Moomaw,W.R. (eds) People and Their Planet: Searching for Balance (pp. 39-52). New York: St Martin's Press,

4. Akowuah, D. K., Rice, K., Merz, A., \& Sackey, V. A. (1975). The children of the gods. Journal of the Ghana Wildlife Society, 1(2), 1922.

5. Anane, M. (1997). Religion and conservation in Ghana, in Alyanok, L. and A. Cruz (eds.), Implementing Agenda 21: NGO Experiences from around the world. New York: United Nations non liaison Services.

6. Baker, L. R., Tanimola, A. A., Olubode, O. S., \& Garshelis, D. L. (2009). Distribution and abundance of sacred monkeys in Igboland, southern Nigeria. American Journal of Primatology: Official Journal of the American Society of Primatologists, 71(7), 574-586.

7. Bhagwat, S. A. (2009). Ecosystem services and sacred natural sites: reconciling material and non-material values in nature conservation. Environmental values, 18(4), 417-427.

8. Bhagwat, S. A. \& Rutte, C. (2006). Sacred groves: potential for biodiversity management. Frontiers in Ecology and the Environment, 4(10), 519-524.

9. Boaten, B. A. (1998). Traditional conservation practices: Ghana's example. Institute of African Studies Research Review, 14(1), 42-51.

10. Campbell, M. O. N. (2004). Traditional forest protection and woodlots in the coastal savannah of Ghana. Environmental Conservation, 31(3), 225-232.

11. Chandrakanth, M. G., Bhat, M. G., \& Accavva, M. S. (2004, May). Socio-economic changes and sacred groves in South India: Protecting a community-based resource management institution. In Natural Resources Forum (Vol. 28, No. 2, pp. 102-111). Oxford, UK: Blackwell Publishing Ltd.

12. Dorm, A., Ampadu, A., \& Veit, P. G. (1991). Religious beliefs and environmental protection: the Malshegu sacred grove in northern Ghana. WRI Washington, DC, USA and Acts Press, Africa Centre for Technology Studies, Kenya. 
13. Dudley, N., Higgins-Zogib, L., \& Mansourian, S. (2009). The links between protected areas, faiths, and sacred natural sites. Conservation Biology, 23(3), 568-577.

14. Elias, D. (2003). Sacred sites in the Tanami desert, central Australia. Paper presented at the The Importance of Sacred Natural Sites for Biodiversity Conservation in Kunming and Xishuagbanna Biosphere Reserve, People's Republic of China, February 17 to 20, 2003.

15. Falconer, J. (1999). Non-timber forest products in Southern Ghana, in Posey, D. (eds.) Cultural and Spiritual Values of Conservation: A Complementary Contribution to the Global Biodiversity Assessment (pp. 366-370).London: Intermediate Technology Press.

16. Fargey, P. J. (1991). Assessment of the conservation status of the Boabeng-Fiema Monkey Sanctuary. Final report to the flora and fauna preservation society, University of Science and Technology, Kumasi.

17. Garcia, C. A., Pascal, J. P., \& Kushalappa, C. G. (2006). Les forêts sacrées du Kodagu en Inde: ecologie et religion. Bois et forêts des tropiques, (288), 5-13.

18. Gomé, G. H. (2003). Forêts sacrées de Côte d'Ivoire : la tradition au secours de l'environnement, pp 33 - 45, Butare, I. (Dans directeur), Les pratiques culturelles. Sauvegarde et conservation de la biodiversité en Afrique de l'Ouest et du Centre: Actes du Séminaire-Atelier de Ouagadougou (Burkina Faso), du 18 au 21 juin 2001, CRDI, Canada, 251 p.

19. Gonedelé Bi, S. E., Bitty, A. E., \& Mcgraw, W. S. (2013, January). Grebouo 1 forest grove in southwestern Cote d'Ivoire is the final refuge for Colobus vellerosus in the Sassandra-Bandama interfluvial region. In American Journal of Physical Anthropology (Vol. 150, pp. 133-133). 111 RIVER ST, HOBOKEN 07030-5774, NJ USA: WILEY-BLACKWELL.

20. Gonedelé Bi, S., Bitty, A., Ouatara, K., \& Scott McGraw, W. (2014). Primate surveys in Côte d'Ivoire's Sassandra-Bandama interfluvial region with notes on a remnant population of black-and-white colobus. African journal of ecology, 52(4), 491-498.

21. Gupta, S. S. (1980). Sacred Trees Across Cultures and Nations. Calcutta: Indian Publications.

22. Gyasi, E. A. (1996, April). Gyamfiase, Ghana: A Study in Threat and Conteracting Threat to Indigenous Forest Groves and Sustainable Forest Management Systems. Paper presented at Workshop on Contested Terrain: West African Forestry Relations, 
Landscapes and Processes. Centre of West African Studies, University of Birmingham, Egbaston, 12-13 April 1996.

23. Hagan, G. P. (1998). Traditional laws and methods of conservation and sustainable use of biodiversity, in Amlalo D.S., L.D. Atsiatorme and C. Fiati (eds.), Proceedings of the third UNESCO MAB Regional Seminar on biodiversity conservation and sustainable development in Anglophone Africa (BRAAF), Cape Coast, 9-12th March 1997. Accra : Environmental Protection Agency (EPA).

24. Khan, M. L., Khumbongmayum, A. D., \& Tripathi, R. S. (2008). The sacred groves and their significance in conserving biodiversity: an overview. International Journal of Ecology and Environmental Sciences, 34(3), 277-291.

25. Khumbongmayum, A. D. (2004). Studies on Plant Diversity and Regeneration of a few Tree Species in the Sacred Groves of Manipur (Ph.D. Thesis). North-Eastern Hill University, Shillong, India.

26. Khumbongmayum, A. D., Khan, M. L., \& Tripathi, R. S. (2004). Sacred groves of Manipur-ideal centres for biodiversity conservation. Current Science, 87(4), 430-433.

27. Khurana, I. (1998). Unnatural decline. Down To Earth 6(23):34-38.

28. Kokou, K. (1998). Les mosaïques forestières au sud du Togo: biodiversité, dynamique et activités humaines (Thèse de Doctorat). Université Montpellier, France.

29. Kokou, K., Afiademanyo, K., \& Akpagana, K. (1999). Les forêts sacrées littorales du Togo: rôle culturel et de conservation de la biodiversité. Journal de la Recherche Scientifique de l'Université de Lomé, 3(2), 97-110.

30. Kouami, K., Kossi, A., \& Klaus, H. (2005). Les forêts sacrées de l'aire Ouatchi au sud-est du Togo et les contraintes actuelles des modes de gestion locale des ressources forestières. VertigO-la revue électronique en sciences de l'environnement, 6(3).

31. Léonard, E., \& Ibo, J. (1997). La SODEFOR, les paysans, la forêt: quel avenir pour la forêt classée de la Niégré et ses occupants?

32. Lucas, A. T. (1963). The sacred trees of Ireland. Journal of the Cork Historical and Archaeological Society, 68(207), 16-54.

33. Malhotra, K. C., Gokhale, Y., Chatterjee, S., \& Srivastava, S. (2001). Cultural and ecological dimensions of sacred groves in India. INSA, New Delhi.

34. Man and the Biosphere Programme Unesco. (1996). Biosphere reserves: The Seville strategy \& the statutory framework of the world network. Unesco.

35. Ntiamoa-Baidu, Y. (1995). Indigenous vs. Introduced Biodiversity Conservation Strategies: The case of protected areas systems in 
Ghana. African Biodiversity Series, Number I, May 1995, 1-11. Washington: The Biodiversity Support Program.

36. Ntiamoa-Baidu, Y., Gyamfi-Fenteng, L. J., \& Abbiw, D. (1992). Management strategy for sacred groves in Ghana. Report prepared for the World Bank and the Environmental Protection Council.

37. Ormsby, A. A. \& Bhagwat, S. A. (2010). Sacred forests of India: a strong tradition of community-based natural resource management. Environmental Conservation, 37(3), 320-326.

38. Powledge, F. (2006). The millennium assessment. AIBS Bulletin, 56(11), 880-886.

39. Rodgers, W. A. (1994). The sacred groves of Meghalaya. Man in India, 74(4), 339-348.

40. Saj, T. L., Mather, C., \& Sicotte, P. (2006). Traditional taboos in biological conservation: the case of Colobus vellerosus at the Boabeng-Fiema Monkey Sanctuary, Central Ghana. Social Science Information, 45(2), 285-310.

41. Saxena, K. G., Rao, K. S., \& Maikhuri, R. K. (1998). Religious and cultural perspective of biodiversity conservation in India: A review. Conserving the Sacred for Biodiversity Management. UNESCO and Oxford-IBH Publishing, New Delhi, 153-161.

42. Schaaf, T. (2003, February). UNESCO's experience with the protection of sacred natural sites for biodiversity conservation. Paper presented in The Importance of Sacred Natural Sites for Biological Conservation-Paris (UNESCO)-Proceedings of the International Workshop, Kunming and Xishuangbanna (pp. 13-20). People's Republic of China, February 17 to 20, 2003.

43. Schaaf, T. \& Rossler, M. (2010). Sacred Natural Sites, Cultural Landscapes and UNESCO's Action. In Verschuuren, B., R. Wild, J. A. McNeely and G. Oviedo. (eds.), Sacred Natural Sites: Conserving Nature \& Culture (pp. 161-169). Earthscan, Washington, DC.

44. Singh, G. S., Rao, K. S., \& Saxena, K. G. (1998). Eco-cultural analysis of sacred species and ecosystems in Chhakinal watershed, Himachal Pradesh. Conserving the Sacred for Biodiversity Management. UNESCO and Oxford-IBH Publishing, New Delhi, 301-314.

45. Sinha, B. \& Maikhuri, R. K. (1998). Conservation through 'sociocultural-religious practice'in Garhwal Himalaya: A case study of Hariyali sacred site. Conserving the Sacred for Biodiversity Management, 299, 289.

46. Tahoux-Touao, M. (2004). Contribution des sites sacrés à la conservation et à la gestion durable de la biodiversité et des valeurs socio-culturelles : le cas de la Côte d'Ivoire in Linking Universal and 
Local Values: Managing a Sustainable Future for World Heritage. World Heritage Series $n^{\circ} 13$.

47. Thierry Tsialiva \& Harizo Rasolomanana (2012). Aménagements écotouristiques au niveau du site Mont Passot: Etude d'impact environnemental et social. Projet pôles intégrés de croissance. Crédit 4399-MAG. 82 pages.

48. Tiwari, B. K., Barik, S. K. \& Tripathi, R. S. (1998). Biodiversity Value, Status, and Strategies for Conservation of Sacred Groves of Meghalaya. India. Ecosystem Health 4(1): 20-32.

49. Tiwari, B. K., Barik, S. K. \& Tripathi, R. S. (1999). Sacred Forests of Meghalaya: Biological and Cultural Diversity: Regional Centre, National Afforestation and Eco-Development Board, North-Eastern Hill University, Shillong.

50. Tutu, K. \& Akol, C. (2009). Reversing Africa's deforestation for sustainable development. In Appropriate technologies for environmental protection in the developing world (pp. 25-34). Springer, Dordrecht.

51. UNESCO (1972). Convention concerning the protection of the world cultural and natural heritage: adopted by the General conference at its seventeenth session, Paris, 16 November 1972. Unesco.

52. Vartak, V. D. \& Gadgil, M. (1981). Studies on sacred groves along the Western Ghats from Maharashtra and Goa: Role of beliefs and folklores. Glimpses of Indian ethnobotany, 272-278.

53. Wild, R., McLeod, C., \& Valentine, P. (2008). Sacred natural sites: guidelines for protected area managers (No. 16). IUCN.

54. Yao, T. B., Servat, E., \& Paturel, J. E. (1998). Contribution à l'analyse des inter-relations entre activités humaines et variabilité climatique: cas du Sud forestier ivoirien. Comptes Rendus de l'Académie des Sciences-Series IIA-Earth and Planetary Science, 327(12), 833-838. 